DOI: $10.34185 / 1991-7848 . i t m m .2020 .01 .027$

\title{
НЕСТАНДАРТНА МОДЕЛЬ ДВОВИМІРНОГО СИМПЛЕКСА Т7
}

Хомченко А. Н., д.ф.-м. н., професор, Литвиненко О.І.,к.т.н., доцент, Астіоненко I.O., к.ф.-м.н, доцент

Чорноморський національний університет ім. Петра Могили, Україна Херсонський національний технічний університет, Україна

Ключові слова: ТРИКУТНИК Т7, НЕСТАНДАРТНА МОДЕЛЬ, ОБЧИСЛЮВАЛЬНИЙ ШАБЛОН, СКІНЧЕННИЙ ЕЛЕМЕНТ, КУСКОВЕ ТЕСТУВАННЯ.

Вступ. Трикутник, як двовимірний симплекс, вважаєте найбільш розповсюдженим СЕ. Одна із причин цього в тому, що будь-яку область у двовимірному просторі можна апроксимувати багатокутниками, які завжди можна розбити на трикутники. Стандартні моделі трикутників різних порядків можна знайти у книгах [1-3]. У роботі розглянуто трикутник Т7, який має сім вузлів (три вузли у вершинах, три вузли на серединах сторін і один вузол у барицентрі). В математиці Т7 використовують у якості обчислювального шаблона для наближеного інтегрування у трикутних областях. Зустрічається трикутник Т4, який також використовують у якості обчислювального шаблону. Засновник сучасного і дуже ефективного методу скінченних елементів (MCE) Р. Курант реалізував свої геніальні ідеї саме на трикутниках (трикутник Куранта, комірка Куранта).

Основна частина. Не всі трикутники здатні виконувати подвійну роль: обчислювального шаблона і скінченного елемента. До скінченних елементів вимоги більш жорсткі, наприклад, залежність між порядком елемента і кількістю вузлів, необхідних для поліноміальної інтерполяції. Ось чому серед трикутних CE зустрічаються тільки члени арифметичного ряду «трикутних» чисел Піфагора: Т3, Т6, Т10... (рис. 1).

У роботі вперше побудовано поліноміальний базис нестандартного трикутника Т7. Доведено, що Т7, як і стандартний Т10, можна використовувати не тільки як обчислювальний шаблон для наближеного інтегрування, a i як скінченний елемент. Якщо ансамблювання СЕ не передбачається (трикутний суперелемент), достатньо сконструювати базис, який задовольняє 
International scientific and technical conference Information Technologies in Metallurgy and Machine building - ITMM 2020

інтерполяційну гіпотезу Лагранжа. Якщо передбачається ансамблювання, треба шляхом кускового тестування дослідити поведінку базису Т7 на границі 3 трикутником Т6 або квадратом Q8. Порушення міжелементної неперервності (несумісність) на границі з трикутним Т6 або квадратним Q8 не має небажаних наслідків. Модель Т7 успішно витримує тестування як за версією АйронсаРаззака, так і за версією Паттерсона.
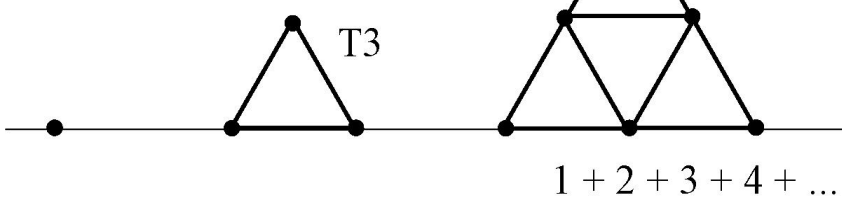

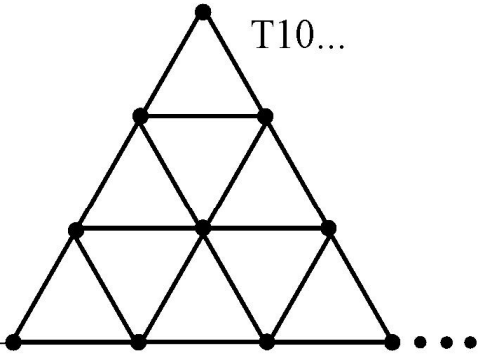

Рисунок 1 - Трикутні числа Піфагора (трикутні СЕ)

Таким чином, отримана нестандартна кубатура для наближеного обчислення подвійних інтегралів на трикутних областях має вигляд:

$$
\iint_{D} f(x, y) d S \approx S \cdot\left(\frac{9}{20} \cdot f_{0}+\frac{1}{20} \sum_{i=1}^{3} f_{i}+\frac{2}{15} \sum_{i=4}^{6} f_{i}\right) .
$$

Цю формулу можна підтвердити методом невизначених коефіцієнтів [4].

Висновки. «Дута» мода Т7 відкриває можливості генерувати шляхом конденсації безліч альтернативних моделей Т6 із різними інтегральними характеристиками.

\section{Література}

1. Mitchell A.R., Wait R. The finite Element Methodin partial differential equations. London: Wiley (1977).

2. Norrie D. H., de Vries G. An introduction to finiteelement analysis, Academic Press, N.Y. (1978).

3. Zienkiewicz O. C., Taylor R.L. The Finite Element Method. Fifth edition. Vol. 1. Bristol Printed and bound by MPG Boks Ltd. Butterworth - Heinemann, (2000).

4. Марчук Г. И., Агошков В. И. Введение в проекционно-сеточные методы. М.: Наука, 1981.416 c. 
NON-STANDARD MODEL OF TWO-DIMENSIONAL SIMPLEX T7

Khomchenko Anatolii, Lytvynenko Olena, Astionenko Ihor

Abstract. The paper considers the triangle T7, which has seven nodes (three nodes in the points, three nodes in the middle of the sides and one node in the barycenter). It is shown that $\mathrm{T} 7$, as well as standard $\mathrm{T} 10$ can fulfill a dual role: both of a computational pattern and a finite element. Violation of inter-element continuity (incompatibility) at the boundary with triangular T6 or square Q8 has no undesirable effects. T7 model successfully withstands lump testing. Upon that the "blown" mode of T7 opens the possibility to generate by condensation many alternative models of T6 with different integral characteristics.

Keywords: T7 TRIANGULAR, NON-STANDARD MODEL, COMPUTATIONAL TEMPLATE, FINITE ELEMENT, LUMP TESTING.

\section{References}

1. Mitchell A.R., Wait R. The finite Element Methodin partial differential equations. London: Wiley (1977).

2. Norrie D. H., de Vries G. An introduction to finiteelement analysis, Academic Press, N.Y. (1978).

3. Zienkiewicz O. C., Taylor R.L. The Finite Element Method. Fifth edition. Vol. 1. Bristol Printed and bound by MPG Boks Ltd. Butterworth - Heinemann, (2000).

4. Marchuk G. I., Agoshkov V. I. Vvedenie v proektsionno-setochnyie metodyi. M.: Nauka, 1981. $416 \mathrm{~s}$. 